\title{
GÉNESIS, DESARROLLO E INSTRUMENTALIZACIÓN DE LA SOCIEDAD AMIGOS DE LOS ÁRBOLES DE A CORUÑA (1911-1983)*
}

\author{
Enrique Carballo Gende \\ Universidad de Santiago de Compostela \\ ORCID iD: https://orcid.org/0000-0001-6172-0712
}

\begin{abstract}
* Grupo de Investigación HISTAGRA-USC (GI-1657) del SUG. Referencia Proxectos Plan Galego de I+D (ED431C 2017111). Agradecimientos: Este artículo parte de un trabajo realizado para una asignatura impartida en el Master de Historia Contemporánea de la Universidad de Santiago de Compostela por los profesores Xesús Balboa López y Eduardo Rico Boquete, a los que agradezco sus respuestas y aportaciones.
\end{abstract}

Copyright: C 2020 CSIC. La edición electrónica de esta revista se distribuye bajo los términos de una licencia de uso y distribución Creative Commons Reconocimiento 4.0 Internacional (CC BY 4.0).

Cómo citar/Citation: Enrique CARBALlo Gende, "Génesis, desarrollo e instrumentalización de la sociedad Amigos de los Árboles de A Coruña (1911-1983)", Cuadernos de Estudios Gallegos, 67, núm. 133 (2020), págs. 351-374, https://doi.org/10.3989/ceg.2020.133.12 


\title{
GÉNESIS, EVOLUCIÓN E INSTRUMENTALIZACIÓN DE LA SOCIEDAD AMIGOS \\ DE LOS ÁRBOLES DE A CORUÑA (1911-1983)
}

\section{RESUMEN}

La sociedad de Amigos de los Árboles de A Coruña nació en 1911 como iniciativa de una parte de las élites y la mesocracia burguesas para celebrar la Fiesta del Árbol. En sus primeros años fue muy activa, y proporcionaba servicios y conocimiento a los socios silvicultores. Mantuvo buenas relaciones con las autoridades y fue clave en la difusión de la Fiesta del Árbol por la provincia, si bien fue perdiendo empuje sobre todo en los años treinta. Sobrevivió a la Guerra Civil, y, pese a ser suspendida durante algunos años de la posguerra, a partir de 1950 volvió a tener actividad hasta 1981. En esta etapa su actividad casi única fue fomentar la Fiesta del Árbol en la provincia de A Coruña, para lo que contó con un apoyo de los gobernadores civiles que contrasta con el conjunto del país, en el que la festividad se había extinguido. Esta resurrección, creemos, tuvo al menos parcialmente carácter propagandístico a favor del Gobierno, y está relacionada con la reforestación por parte del Estado de los montes comunales gallegos, de interés estratégico y económico para las autoridades pero que generó oposición por parte de los habitantes del campo. PALABRAS ClAVE: Fiesta del Árbol, A Coruña, sector forestal, repoblación, franquismo.

\section{XÉNESE, EVOLUCIÓN E INSTRUMENTALIZACIÓN DA SOCIEDADE DE AMIGOS DE LOS ÁRBOLES DE A CORUÑA (1911-1983)}

\section{RESUMO}

A sociedade de Amigos de los Árboles de A Coruña naceu en 1911 como iniciativa dunha parte das elites e a mesocracia burguesas para celebrar a Fiesta del Árbol. Nos seus primeiros anos foi moi activa, e proporcionaba servizos e coñecemento aos socios silvicultores. Mantivo boas relacións coas autoridades e foi clave na difusión da Fiesta del Árbol pola provincia, aínda que foi perdendo empuxe sobre todo nos anos trinta. Sobreviviu á Guerra Civil, e, a pesar de ser suspendida durante algúns anos da posguerra, a partir de 1950 volveu ter actividade ata 1981. Nesta etapa a súa actividade case única foi fomentar a Fiesta del Árbol na provincia da Coruña, para o que contou cun apoio dos gobernadores civís que contrasta co conxunto do país, no que a festividade estaba extinta. Esta resurrección, cremos, tivo polo menos parcialmente carácter propagandístico en favor do Goberno e está relacionada coa reforestación por parte do Estado dos montes comunais galegos, de interese estratéxico e económico para o Goberno pero que xerou oposición por parte dos habitantes do campo.

Palabras Clave: Fiesta del Árbol, A Coruña, sector forestal, repoboación, franquismo.

\section{ORIGINS, EVOLUTION AND INSTRUMENTALIZATION \\ OF THE SOCIETY AMIGOS DE LOS ÁRBOLES OF A CORUÑA (1911-1983)}

\begin{abstract}
Amigos de los Árboles of A Coruña was born in 1911 as an association of members of the city's elites and mesocracy to celebrate the Fiesta del Arbol. In these early years it was very active, and provided services and knowledge to the forestry partners. It held good relations with the authorities and had key role in the dissemination of the Fiesta del Árbol in the province, although its drive declined in later years, especially in the 30s. Amigos de los Arboles survived the Civil War, and despite being suspended for some years after the war, in 1950 it became active again and until 1981. In this stage the promotion of the Fiesta del Arbol in the province of A Coruña was almost its only activity. In this task it had a surprising support of the civil governors; in the rest of Spain this holiday was becoming extinct. This resurrection and public support was in part propaganda of the Government activities, and is related to the reforestation by the State of the Galician communal lands. The reforestation held and strategic and economic interest to the Government, but was rejected by the inhabitants of the countryside.

KeY woRDs: Fiesta del Árbol, A Coruña, forestry, reforestation, Francoism.
\end{abstract}




\section{Celebración de eCología y de nación: la Fiesta del Árbol}

La sociedad coruñesa de Amigos de los Árboles se fundó en 1911 y subsistió, si bien con importantes transformaciones, hasta 1981. Para estudiar su evolución hemos empleado dos fuentes documentales primarias. Una es el diario corunés La Voz de Galicia, que se publicó de manera ininterrumpida durante todo este periodo y que cuenta con números digitalizados para el periodo estudiado. Hemos buscado automáticamente todas las páginas con los términos clave Amigos de los Árboles o Fiesta del Árbol, encontrando varios centenares de resultados. En el texto se muestra una selección.

La otra son los archivos relativos a la asociación que se conservan en el Archivo del Reino de Galicia, donde se encuentran los fondos del Gobierno Civil. La documentación de relevancia acerca de su constitución y trayectoria es fragmentaria, y se concentra en su fundación y los años cuarenta y sesenta. En 1911 encontramos el reglamento de la asociación, y su primera relación de cargos, que incluye un acta fundacional. En la posguerra, en los años 1941 y 1942, tenemos el único listado de socios que hemos podido recuperar, un inventario de bienes, varias comunicaciones al Gobierno civil y un informe policial sobre sus componentes. En la década de 1960 hay nueva documentación, y en 1964 y 1965 hallamos de nuevo cuentas y un informe de la Guardia Civil sobre la junta directiva. La falta de continuidad de esta documentación da una visión truncada de la evolución de la asociación, por lo que su trayectoria se ha seguido sobre todo a través de fuentes hemerográficas, apoyadas por la propia producción editorial de Amigos de los Árboles.

Durante las siete décadas de existencia de la asociación, su actividad más longeva y significativa fue la celebración de la Fiesta del Árbol. Esta fue, además, el catalizador de su creación. Antes de examinar a la asociación desde otros ángulos, es necesario entender qué significaba en la España de la época y a qué intereses sirvió esta celebración. Diversos pueblos españoles defendieron una tradición de Fiestas del Árbol avant la lettre, como Villanueva de la Sierra ${ }^{1}$ o

\footnotetext{
1 Rafael Codorniu, La fiesta del árbol. Recuerdos, datos, consejos, himnos, poesías, máximas y pensamientos (segunda edición), Madrid, Imprenta alemana, 1915, pág. 4.
} 
Mondoñedo ${ }^{2}$, pero esta nació en Nebraska en 1872 y que en los años siguientes se difundió por el resto de Estados Unidos y por Europa ${ }^{3}$. En España se convirtió en la principal celebración laica de las dos primeras décadas del siglo XX. El papel especial que brindaba el Regeneracionismo a la naturaleza y los bosques contribuyó sin duda a difundirla ${ }^{4}$, pero para consolidarla fue clave el apoyo institucional por parte de un pequeño círculo de políticos y la Corona $^{5}$, que apadrinaron la primera celebración en 1896.

En 1904 el Estado emitió un decreto para promocionar y regular la celebración de la fiesta, ligándola a las élites locales. Además de establecer apoyos y subvenciones, recomendaba que en las juntas locales participasen el alcalde, el párroco y el médico y maestros más destacados del lugar 6 . Posteriormente se abrieron líneas de ayudas y premios ${ }^{7}$. El legislador tenía en mente una festividad centrada en torno al municipio, pero continuaron las fiestas organizadas por particulares. En septiembre de 1912, según el ingeniero de montes Codorniu, se ofrecieron 573631 plantas desde viveros públicos para celebrar la fiesta ${ }^{8}$. En 1914 se obligó a todos los empleados del servicio forestal a celebrar una Fiesta del Árbol allí donde residiesen ${ }^{9}$, y en 1915, por Real Decreto, la obligación se extendió a todos los Ayuntamientos ${ }^{10}$. La aplicación, sin embargo, fue laxa ${ }^{11}$.

El programa solía consistir en una excursión de los alumnos de educación primaria de una localidad a un terreno inculto en el que se plantaban árboles, seguida de un acto formal, con discursos y lecturas públicas, y, a veces, de una velada literaria intramuros $u$ otras actividades ${ }^{12}$. Se comercializaron textos para su lectura en estos eventos, y Fernando José de Larra, Premio Nacional de Literatura, escribió

\footnotetext{
2 Homenaje a Luis de Luaces y Labrada Regidor de Mondoñedo, señor de Abadín y Lagoa de Montes de Meda: por haber celebrado en Mondoñedo, en el siglo XVI, la primera Fiesta del Arbol de España de que hay noticia, Mondoñedo, ayuntamiento de Mondoñedo, 1940. En la fiesta colaboró una delegación de Amigos de los Árboles.

3 José Miguel Sierra Vigil, La culta y simpática fiesta: la Fiesta del Árbol en la política forestal y la historia de España, Madrid, Ministerio de Medio Ambiente y Medio Rural y Marino, 2011, págs. 35-37.

4 Santos Casado de Otaola, Los primeros pasos de la ecología en España, Madrid, Centro de Publicaciones del Ministerio de Agricultura, Pesca y Alimentación, 1997, págs. 319-329.

5 Sierra Vigil, La culta..., págs. 116-119.

6 Real Decreto del 11 de marzo de 1904. Gaceta de Madrid (12-03-1904), pág. 1.023. Más tarde se incorporó a los miembros recomendados de la Junta el farmacéutico con más tiempo de residencia. $L a$ Gaceta de Madrid (30-07-1904), pág. 1.111.

7 Eduardo RICO Boquete, "Los ingenieros de montes y la propaganda forestal: la fiesta del árbol en España”, Revista Forestal Española, 12 (1995), pág. 35.

8 Codorniu, La fiesta...pág. 9. En la primera mitad de esta década tuvieron un hubo un crecimiento muy importante en el número de actos. Según Rico Boquete, y calculando por defecto, se pasó de 31 en 1910 a más de 500 en 1913 y 1914. Rico Boquete, "Los ingenieros...”, pág 36.

$9 \quad$ La Gaceta de Madrid (19-10-1914), pág. 163.

${ }^{10}$ La Gaceta de Madrid (06-01-1915), pág. 48

11 Sierra Vigil, La culta...pág. 199

12 Rico Boquete, "Los ingenieros...", pág. 33.
} 
una pieza teatral infantil sobre la Fiesta del Árbol ${ }^{13}$. Los maestros y maestras eran figuras clave, pero vemos con frecuencia el sacerdote, el alcalde y, en determinadas localidades, el ingeniero de montes, y ocasionalmente miembros de las sociedades obreras o representantes de las Fuerzas Armadas y la judicatura ${ }^{14}$.

La afluencia a la fiesta de gran número de niños en edad escolar, y de muchos adultos, la convertía en un excelente canal para la propaganda. En la práctica, buscaban más implantar valores sentimentales en los futuros ciudadanos que difundir un conocimiento científico ${ }^{15}$. Pese a que hubo algunos intentos de cimentar una celebración apolítica, o incluso republicana y laica ${ }^{16}$, lo más frecuente fue la promoción de Dios y España. La dimensión religiosa es clara tras la Guerra Civil, pero ya antes vemos que muchas veces la fiesta viene acompañada de una misa, y ocasionalmente un sacerdote bendice los árboles. El carácter patriótico iba en dos sentidos: la fiesta servía para reforzar ideológicamente al régimen vigente, identificado con la nación, y al mismo tiempo la repoblación se entendía, en sí misma, como un acto favorable a los intereses españoles ${ }^{17}$. Plantar árbol era, casi, un acto de defensa activa de España, y como tal se explicita en libros para público infantil ${ }^{18}$. Además se reafirmaba el sentido de colectividad con una actividad comunitaria y se la vinculaba con una planta noble, asociación que compartían otros nacionalismos ${ }^{19}$. Muy frecuentemente, los textos ponen a la fiesta el apellido de patriótica además del de culta ${ }^{20}$.

El signo político, por supuesto, iba variando. En 1932, en la fiesta coruñesa suenan el Himno de Riego, el Himno Gallego y la Marsellesa ${ }^{21}$. En 1937, con la ciudad en la zona sublevada, al Himno al Árbol lo acompañaron el Canto a la Bandera y el Himno a la Legión ${ }^{22}$.

También sirvió para promocionar políticas forestales concretas y defensa de programas políticos. En 1926, el sacerdote de la parroquia de Bacoi, en Alfoz,

\footnotetext{
${ }^{13}$ Fernando José DE LARra, "La fiesta del árbol”, en Fernando José de Larra, La fuente de los amores, La escuela nueva, La fiesta del árbol, Madrid, Yagües, 1929, págs. 65-76.

${ }^{14}$ Ezequiel Solana, La fiesta del árbol (segunda edición), Madrid, El Magisterio Español, 191?, pág. 17-25.

${ }^{15}$ Casado de Otaola considera la Fiesta del Árbol una forma válida, pero limitada, de acercar a niños y adultos hacia la cultura sentimental del bosque, lo que nos parece una definición muy acertada de su naturaleza. CASAdo dE OTAOLA, Los primeros..., págs. 299-305.

16 Sierra Vigil, La culta...págs. 49, 63, 75, 93, 144-146.

17 Desde el siglo XIX no solo la defensa de la naturaleza, sino su investigación, incluye un componente nacionalista y regenerador. CASADO DE OTAOLA, Los primeros...pág. 49-50.

18 Juan Cruz Busto, Recuerdo grato de la Fiesta del Árbol. Árboles, pájaros, agricultura, etc, Logroño, El Riojano, 1900, págs. 8-9.

19 Jennifer BRADY, "El árbol y la nación: la creación de nacionalidad catalana en dos obras noucentistes", Espéculo. Revista de estudios literarios (2008).

20 Rico Boquete, “Los ingenieros...”, pág. 34.

${ }^{21}$ La Voz de Galicia (01-03-1932), pág. 6.

${ }^{22}$ La Voz de Galicia (29-01-1937), pág. 1.
} 
aprovechó su discurso de la Fiesta del Árbol para subrayar el gran amor al árbol de la Iglesia Católica, pero también para intentar convencer a sus feligreses de las bondades de la repoblación de los montes circundantes, emprendida por el Estado. Estas tierras, afirmaba, habían pasado mucho tiempo abandonadas a la incultura y esterilidad, debido al punible abandono del Estado entregado a los caciques de la Restauración, pero la situación estaba entonces cambiando gracias al golpe de Fuerza de Primo de Rivera y el culto y activo alcalde que ocupaba entonces el Ayuntamiento. Los vecinos, afirmaba el sacerdote, debían cooperar de una manera decidida y entusiasta con la repoblación ${ }^{23}$. En el programa de actividades de la Fiesta del Árbol de Mondoñedo de 1940 se incluía un discurso sobre el decreto de repoblación forestal de S. E. el Generalísimo, que concede 33 millones de pesetas para fin tan patriótico ${ }^{24}$.

\section{FundaCión y AÑos DORADos de Amigos de los Árboles (1911-1920)}

La primera Fiesta del Árbol del municipio de A Coruña se celebró en marzo de 1911, a iniciativa de la Liga de Amigos de La Coruña, una asociación de la burguesía coruñesa que promovía actividades y festejos en colaboración con el Ayuntamiento. El 14 mayo de ese mismo año la Sociedad de Amigos de los Árboles de La Coruña ${ }^{25}$, se constituyó como asociación propia, con vistas a celebrar una nueva edición. Tras un ensayo con una pequeña fiesta en $\mathrm{Oza}^{26}$, los miembros organizaron una Fiesta del Árbol el 25 de febrero de 1912 que contó con el apoyo del Gobierno local ${ }^{27}$. De acuerdo con una de las crónicas, en ella participaron cuatro mil escolares, una inmensa muchedumbre de ciudadanos y las autoridades civiles y militares ${ }^{28}$. Se plantaron varios miles de árboles y se repartieron, además de la tradicional merienda para los niños, flores y medallas. Amigos de los Árboles repitió el evento en los dos años siguientes, y en 1915, cuando el Ayuntamiento se vio obligado a celebrar la fiesta por decreto, en la práctica se limitó a proporcionar a la sociedad una subvención similar a la de años anteriores, delegando en ella parte de la organización. Empezaba así una colaboración que duraría décadas.

\footnotetext{
23 José Martínez CoBo, Discurso pronunciado por D. José Martínez Cobo, Cura párroco de Bacoy, en la "Fiesta del Árbol" celebrada en Alfoz del Castro de Oro el 14 de marzo de 1926, Mondoñedo, Imprenta Popular, 1926.

${ }^{24}$ Homenaje a Luis de Luaces y Labrada...

${ }_{25}$ Reglamento de la sociedad de Amigos de los Árboles, 1911.

${ }^{26}$ La Voz de Galicia (25-02-1912), pág. 1.

${ }^{27}$ La Voz de Galicia (10-05-1912),pág. 2; La Voz de Galicia (29-01-1912), pág. 1; La Voz de Galicia (2502-1912), pág. 2.

${ }^{28}$ LAGE, "La fiesta del árbol", en Suevia: revista gallega, Santiago de Compostela, Dirección Xeral de Política Lingüística, Centro Ramón Piñeiro para a Investigación en Humanidades, 1999, págs. 5-6. [Ed. facsimile de la revista Suevia: revista gallega publicada en La Habana en 1910-1912].
} 
El reglamento de la sociedad estableció una ambiciosa lista de trece puntos. Pueden resumirse en promover el arbolado y la fauna avícola (en especial la cría de palomas), defender los intereses de los propietarios forestales, facilitar el acceso a semillas, maquinaria y otros insumos de forma colectiva, difundir el conocimiento del sector a través de conferencias y una biblioteca circulante (también $a$ los niños y a los obreros), celebrar excursiones y organizar la Fiesta del Árbol. En cuanto a los socios, admitía a particulares y colectivos, y en su junta se combinaban cargos electos con una larga serie de puestos reservados a diversos cargos e instituciones, que iban mucho más allá de lo recomendado en el decreto de 1904. Cubrían a todas las fuerzas vivas de la ciudad, pero también a cargos de la Administración relacionados con el sector primario ${ }^{29}$. La constitución formal se produjo el 4 de junio de 1911, en una sesión en la que, según interpretamos de un párrafo de redacción confusa, la Universidad Popular y las sociedades obreras ofrecieron apoyo económico para difundir la labor de la sociedad a través de Martínez Morás. Uno de los puntos de esta sesión inaugural fue explicitar el derecho de las mujeres a ser socias, reconociendo que su labor puede ser altamente beneficiosa para los fines que se persiguen. La asociación iniciaba así su recorrido tendiendo una mano a los obreros y a las mujeres, pero los trece miembros de la primera junta directiva son hombres ${ }^{30}$. De ellos, hemos podido identificar a nueve como miembros de la burguesía coruñesa, en su mayoría profesionales liberales, junto con algún industrial o ex militar. Otro parece ser miembro del linaje de los Mariño, bien posicionado, y el undécimo, Jesús Barreiro Costoya, era miembro de la Real Academia Gallega.

Ciertamente la mayoría no tiene relación con el sector primario, pero era la tónica de la época ${ }^{31}$, y ya hemos señalado que se reservaron puestos en la directiva para profesionales de perfil técnico. El primer presidente de la asociación fue el catedrático de Agricultura del Instituto Coruñés, José Hernansáez Meoro y más tarde lo sería el ingeniero agrónomo Juan Sanz de Andino (y, aunque con una

\footnotetext{
${ }^{29}$ En concreto: el alcalde, el médico y párrocos más antiguos de la localidad, el maestro de escuela de mayor categoría, el mayor contribuyente, el presidente de la comisión del Arbolado, el ingeniero jefe del Distrito Forestal, el de la región agronómica, el de obras públicas, el catedrático de agricultura del instituto, el ingeniero encargado de la sección de cultivos de la Granja Agrícola, el jefe del Consejo Provincial de Fomento, un representante del Ejército, otro de la Cámara Agrícola, un tercero de las sociedades obreras y los directores de los diarios locales. Debe entenderse como una propuesta de máximos, y a bien seguro muchos no acudían a las reuniones. Reglamento...(1911), pág. 11.

${ }^{30}$ Relación de cargos de la Junta Directiva de Amigos de los Árboles, 8 de junio de 1911: ArCHIVO DEL Reino de Galicia (en adelante ARG), caja 32094, legajo 2.

${ }^{31}$ En 1913, en Carballo, se organizó una rifa a través de boletos Garcybarra para financiar la fiesta del año siguiente. La junta estaba formada por el alcalde, el juez de primera instancia, un cura párroco, el médico más antiguo, un maestro de cada sexo, dos hombres a los que se designa como mayor contribuyente, y dos individuos a los que solo se designa como secretario y depositario.La Voz de Galicia, (12-07-1913), pág. 2.
} 
ligazón más tenue con lo forestal, el veterinario Juan Rof y Codina ${ }^{32}$. Aunque no lo hemos encontrado en la directiva, una referencia periodística indica que es posible que el divulgador de la naturaleza Valeriano Villanueva fuese socio en los primeros años ${ }^{33}$. Al tiempo, encontramos miembros prominentes con una relación con la naturaleza más de aficionado, como Manuel Insua Santos, muy conocido en la ciudad. Era el promotor por aquella época de la Sociedad de Amigos del Campo, grupo de excursionistas que colaborará estrechamente con Amigos de los Árboles. Hernansáez en 1917 describió la asociación como un grupo de amigos, en su mayoría ajenos por completo a las cuestiones agrícolas, pero con alta conciencia patria ${ }^{34}$.

Entre los vocales electos en junio de 1911 se encuentran varios jóvenes ligados a los círculos republicanos, que bordeaban en estos tiempos los treinta años: junto al ya mencionado Fernando Martínez Morás tenemos a Manuel Monteagudo ${ }^{35}$, y también al político republicano Gerardo Abad Conde (primero aliado y luego enemigo de Santiago Casarés Quiroga en la política local y ministro de Marina en el bienio radical-cedista) y a Joaquín Martín Martínez (que sería más tarde secretario municipal, y uno de los pocos fusilado por los sublevados en la ciudad). No resulta extraño, ya que A Coruña era mayoritariamente republicana, y la generación nacida en 1880 fue particularmente activa. Pero en la lista de nombres también está el abogado José Asúnsolo Obanza, que había hecho carrera como político conservador como yerno de Maximiliano Linares Rivas, o el empresario conservero Jenaro Fernández Sánchez ${ }^{36}$. En resumen, no parece que la organización tuviese una fuerte afiliación partidista, ni en estos momentos ni en lo sucesivo.

La década en la que se fundó fue sin duda la más fecunda en actividades, y los miembros tomaron un papel activo como silvicultores. Las primeras plantaciones son en terrenos de socios, de pinos marítimos e insignis recibidos de los depósitos forestales de Pontevedra y Navarra ${ }^{37}$. La sociedad organizó por sí misma la repoblación de parcelas incultas y parques de A Coruña, con permiso del Ayun-

\footnotetext{
32 La Voz de Galicia (20-03-30), pág. 1.

${ }^{33}$ LAGE, "La fiesta del árbol...” pág. 6.

34 José María Hernansáez Meoro, Árboles interesantes para Galicia: el castaño, instrucciones para su propagación, La Coruña, Papelería y talleres de la imprenta Garcybarra, 1917, pág. 6.

35 Ambos forman parte del grupo de estudantes da Escola de Comercio que se reunían no mesmo local da Cova Céltica desde 1898. Antón CAPELÁn ReY, "Contribucións a unha historia da Universidad Popular da Coruña”, Sarmiento, 3 (1999), pág. 32.

36 Ángel I. Fernández GonzÁLEZ., "Los Cerdeiras. Armadores, fomentadores y conserveros de la Costa da Morte”, en Xosé Carmona Badía (dir. y coord.), Las familias de la Conserva. El sector de las conservas de pescados a través de sus sagas familiares, Pontevedra, Diputación de Pontevedra, Fundación Clúster da Conservación de Productos del Mar, 2011, pág. 298.

${ }^{37}$ La Voz de Galicia (04-01-1912), pág. 2.
} 
tamiento o en colaboración con la compañía de ferrocarriles ${ }^{38}$, si bien su obra quedaba a veces deslucida cuando ciudadanos no muy concienciados con los valores forestales destrozaban los árboles o dejaban que su ganado se alimentase de las plántulas ${ }^{39}$. En el monte de Santa Margarita se arbolaron varias parcelas fuera del ámbito de la Fiesta del Árbol, con la colaboración de los alumnos de escuelas primarias públicas y privadas ${ }^{40}$.

Otra labor central era la de organizar pedidos de árboles y semillas en grandes cantidades, para luego cederlos a Fiestas del Árbol, repartirlos entre sus socios a precio de coste o incluso regalarlos a aquellos que se comprometiesen a repoblar ciertas zonas $^{41}$, una tarea que se veía favorecida por los viveros públicos creados por un decreto de $1906^{42}$. A través de estos pedidos llegaron a Galicia especies alóctonas o poco frecuentes, y nuevas variedades ${ }^{43}$. Además, en esta primera década encontramos diversas iniciativas menores: un concurso de repoblación, conferencias, la participación en la comisión municipal de Paseos y Arbolado para cambiar los métodos de poda del Ayuntamiento, el reparto de folletos, la recolección de variedades autóctonas de castaño para su clasificación científica, la concesión de medallas o las gestiones, conjuntas con las asociaciones agrícolas, para que el Estado facilitara la importación de cinco mil toneladas de fertilizante ${ }^{44}$.

La sociedad, recordemos, se ocupaba de la naturaleza en sentido amplio, aunque sus simpatías parecen limitadas a un pequeño número de especies animales. En sus inicios había una sección colombófila, que participa en sueltas de palomas mensajeras ${ }^{45}$, y suficiente sensibilidad hacia las aves como para protestar contra la crueldad y desamor del tiro al pichón y pedir que se eliminara de los festejos coruñeses $^{46}$. Colaboraron también en la Fiesta del Pez, en Pontedeume, que se celebró en la villa en 1914 con una suelta de unas 5000 truchas y salmones en el Eume. En ella, Hernansáez impartió una conferencia sobre piscicultura ${ }^{47}$. Preci-

\footnotetext{
${ }_{38}^{38}$ La Voz de Galicia (21-01-1913), pág. 3); La Voz de Galicia (30-01-1913), pág. 2, La Voz de Galicia (05-03-1919), pág. 2.

${ }^{39}$ La Voz de Galicia (17-12-1919), pág. 3; La Voz de Galicia (05-07-1935), pág. 7.

${ }^{40}$ La Voz de Galicia (06-03-1919), pág. 2; La Voz de Galicia (18-03-1919), pág. 1.

${ }^{41}$ La Voz de Galicia (26-10-1919), pág. 1; La Voz de Galicia (24-02-1917), pág. 2.

${ }^{42}$ Rico Boquete, Los ingenieros..., pág. 36.

43 Por ejemplo, en 1916 se plantan en A Coruña distintas especies de árboles aportadas por Amigos de los Árboles, entre ellas robles americanos y del país, fresnos, arces, catalpas, pinos y acacias, y en esta época se contacta con un proveedor nipón para importar a Galicia semillas de castaño del Japón, que se esperaba fuese inmune a la tinta. La Voz de Galicia (18-01-1916), pág. 1; (05-10-1916), pág. 1.

${ }^{44}$ La Voz de Galicia (19-11-1911), pág. 2.; La Voz de Galicia (26-11-1911), pág. 1; La Voz de Galicia (01-01-1912), pág. 2.; La Voz de Galicia (20-09-1912), pág. 2., La Voz de Galicia (12-02-1917), pág. 1., La Voz de Galicia (15-01-1918), pág. 2., La Voz de Galicia (12-01-1919), pág. 1.

${ }^{45}$ La Voz de Galicia (06-08-1911), pág. 1.

${ }^{46}$ La Voz de Galicia (10-12-1912), pág. 1.

${ }^{47}$ La Voz de Galicia (27-05-1914), pág. 2. En 1915 la Jefatura de Montes de Navarra y Vascongadas, disculpándose por no poder enviar plantas a Amigos de los Árboles, ofreció 20000 huevecillos de salmón
} 
samente en Pontedeume celebraron en 1915 una Fiesta del Árbol Frutal, de las pocas que se realizaron en España en esta época, y que también se intentó organizar en Carballo ${ }^{48}$.

Sería exagerado hablar de grupo de presión (lobby) en el sentido moderno, pero los socios trataron de influir y recabar apoyos de políticos e instituciones. En 1911 una delegación se reunió con Fernández Latorre, propietario de La Voz de Galicia y diputado en Cortes, para pedirle ayuda en sus proyectos. Éste les prometió apoyo para celebrar la Fiesta del Árbol y crear un gran parque en la ciudad $^{49}$. En 1913 pide al Ayuntamiento que interrumpa la reforma de los jardines públicos, talando hermosas y lozanas plantaciones y emprenda otras obras para ocupar a los obreros ${ }^{50}$, y en alguna ocasión la prensa reclamó su movilización en clave de política local ${ }^{51}$. Además de las subvenciones del Ayuntamiento, que serán una constante a lo largo de la historia de la sociedad, recibió ayudas de Fomento ${ }^{52}$ y apoyo de las autoridades militares ${ }^{53}$.

Al tiempo, Amigos de los Árboles jugó un papel destacado en la difusión de la Fiesta del Árbol en la provincia. Además de proporcionar ejemplo, su solvencia económica en estos primeros años le permitía prestar apoyo a celebraciones más modestas $^{54}$, sobre todo con árboles y materiales impresos. Ya antes de 1915 los encontramos como organizadores o colaboradores en eventos organizados en Ares, Cambre, Neda, Cee, San Pedro de Nós, Pontedeume, Fene, Caión o Finisterre $^{55}$ y enviando árboles a otros. En 1916, Amigos colaboró en 63 fiestas del árbol celebradas en la provincia ${ }^{56}$. Si distribuimos las fiestas del árbol en base a las actuales comunidades autónomas, Galicia fue la tercera comunidad en la que más celebraciones se realizaron en el periodo 1912-1914, y más de la mitad de

para el Laboratorio Ictiogénico de Pontedeume, para continuar la repoblación del Eume e iniciar la de algún río más. La Voz de Galicia (12-01-1915), pág. 3.

${ }^{48}$ La Voz de Galicia (24-02-1915), pág. 2; La Voz de Galicia (07-02-1915), pág. 3.. Quizás también se celebró en Ferrol. Sierra Vigil, La culta ..., pág. 193.

49 La Voz de Galicia (27-07-1911), pág. 1.

${ }^{50}$ La Voz de Galicia (26-02-1913), pág. 1.

${ }^{51}$ Así, en 1913 La Voz de Galicia reclama que la asociación proteste contra unas talas llevada a cabo por el Ayuntamiento y que vinculan con la mayoría republicana en el pleno, a quienes se les da un bledo del arbolado y de la salud del pueblo, si de él depende!. La Voz de Galicia (21-10-1913), pág. 2.

${ }^{52}$ La Voz de Galicia (10-06-1913), pág. 1.

${ }^{53}$ La Voz de Galicia (29-01-1914), pág. 1.

${ }^{54}$ En la reunión para formular los presupuestos de 1913 se constató que la sociedad contaba con más de 1250 pesetas en caja, una cantidad significativa para la época, y, previendo superávit para el ejercicio siguiente, se aprobó otorgar auxilios a las Asociaciones de Amigos de los Árboles que se constituyan en la provincia. La Voz de Galicia (12-10-1912), pág. 1.

${ }^{55}$ La Voz de Galicia (22-02-1913), pág. 2; La Voz de Galicia (01-03-1913), pág. 1-2; La Voz de Galicia (16-02-1914) pág. 1; La Voz de Galicia (06-03-1914), pág, 1; La Voz de Galicia (20-03-1914), pág. 2; La Voz de Galicia (28-03-1914), pág. 2.

56 La Voz de Galicia (09-01-1917), pág. 2. 
ellas tuvieron lugar en la provincia de $\mathrm{A}$ Coruña ${ }^{57}$. En cuanto al número de socios, un ingeniero de montes contemporáneo afirma en 1919 que contaba con $260^{58}$.

\subsection{La labor editorial y su reflejo en ella de las aproximaciones al árbol: utilitaria y naturalista}

En la década de 1910 Amigos de los Árboles asumió también la edición de obras de ensayo y de ficción, faceta que parece hallarse ausente en los años siguientes, con la excepción de la impresión de folletos. A la altura de 1917 había publicado tres monografías de intención divulgativa; dos conferencias; media docena de cuentos, uno de ellos en gallego, seguramente con intención de llegar al público infantil; y un obsequio a los niños en la Fiesta del Árbol de $1916^{59}$. Encontramos, por tanto, una producción escrita dirigida a dos públicos bien diferenciados: un público infantil y generalista, al que se apelaba en las Fiestas del Árbol y al que se pretendía estimular en valores naturalistas a través de fábulas moralizantes, y otro adulto, especializado, al que se intenta acercar la silvicultura de manera científica. Un repaso a las tres monografías publicadas por Amigos de los Árboles nos informa, asimismo, de sus actitudes ideológicas en esta primera época.

La primera publicación, fechada en 1913, inaugura la serie Árboles maderables interesantes para Galicia. Instrucciones para su propagación, y lleva por nombre El eucalipto. Con apenas 16 páginas y sin autor explícito, es un alegato a favor de esta especie basándose en criterios economicistas. En la introducción, señala su intención de crear en las escuelas parroquiales un semillero de eucaliptos (y más tarde de otras especies) que los niños puedan trasplantar en los terrenos abandonados próximos a sus viviendas, cuidarlos y venderlos al llegar a la edad adulta. El eucalipto se presenta como un modo de mejorar a un tiempo las condiciones naturales, económicas y sociales al describir las virtudes de la repoblación: a más árboles en los montes, más prados en los valles; a más prados, más ganado; a más ganado más riqueza, y a más riqueza, menos emigración ${ }^{60}$. Esta continuidad es quizás dudosa en la Galicia de esta década, donde los árboles en los montes significaban menos ganado y estiércol, y por tanto menor producción agraria $^{61}$, pero la intención del argumento es clara.

\footnotetext{
57 Sierra Vigil, La culta..., pág. 148-149.

58 Ángel Carrera Cejudo, "La repoblación forestal. Un año en Galicia”, pág. 218, originalmente Madrid, 1920. Citado en Eduardo Rico Boquete (ed.), Pensamento forestal no século XX, Santiago de Compostela, Consellería de Agricultura, Gandería e Política Agroalimentaria, Caixa Ourense, 1999, págs. 139-154.

${ }^{59}$ Hernansáez Meoro, Árboles interesantes..., pág. 31; La Voz de Galicia (31-01-1914), pág. 1.

${ }^{60}$ El eucalipto: árboles maderables interesantes para Galicia. Instrucciones para su propagación, La Coruña, Imprenta y Papelería de F. García Ybarra, 1913, págs. 3-5.

${ }^{61}$ Xesús Balboa López, O monte en Galicia, Vigo, Edicións Xerais de Galicia, 1990.
} 
A continuación, se encuentran informes positivos acerca del potencial de crecimiento del eucalipto en el suelo gallego, su utilidad para colonizar montes de baja calidad, los usos y calidad de su madera y su rendimiento económico, acompañados de instrucciones prácticas acerca de su reproducción, plantación, poda y aprovechamiento, probablemente derivadas de la propia experiencia práctica de los autores. El criterio naturalista está, por tanto, mayoritariamente ausente, aunque el lector pueda entrever, entre las virtudes de la repoblación anunciadas, la lucha contra la erosión.

Cuando dos años después se publica la segunda monografía de la asociación, La poda del arbolado, encontramos una sensibilidad diferente ${ }^{62}$. No es una obra de un experto, sino de la junta directiva. El libro incluye un pequeño número de recomendaciones acerca de las reglas y técnicas a seguir para la poda, pero, sorprendentemente, se opone explícita y frontalmente a esta práctica. Los autores recalcan que Solamente deben podarse los árboles frutales, y esto en el caso de que se tenga la seguridad de que la operación va a ser bien hecha. En todos los demás árboles debe prohibirse en absoluto la poda [cursiva en el original]. Esta, según el libro, se realiza forzando la naturaleza del árbol, y con ella, en todos los casos, se les estenua [sic] y acorta la vida. Las citas sobre los podadores son muy agresivas: se habla de los verdugos de los árboles, de la terrible plaga de los que se llaman podadores, del hacha destructora del llamado podador.

La obra nos indica que al menos una porción de los miembros de la sociedad veía el árbol como un ser valioso en sí mismo, no solo por su rendimiento, y que asumían postulados naturalistas bastante radicales para su época. No es la única manifestación de la agrupación en este sentido: en 1929, los socios de Amigos de los Árboles y de su sociedad hermana Amantes del Campo se comprometen, en el desfile de Carnaval, a no aplaudir ningún adorno de carroza u otro objeto de exhibición en que se empleen ramas de árboles, indicadoras de que se destruyó el ejemplar en que aquellas se arrancaron ${ }^{63}$. En las quejas remitidas a los diarios encontramos un lenguaje que humaniza a las plantas. Un plátano talado es sacrificado en un arboricidio cometido sigilosamente, según Vidal Rúa, pese a que Amigos de los Árboles había recibido promesas del Ayuntamiento en sentido contrario $^{64}$. Un árbol que sostiene un poste telefónico está preso con alambre, y se suplica a la Diputación que se lo deje en libertad $^{65}$. Tras una excursión de Amantes del Campo a Almeiras, esta asociación y Amigos de los Árboles suplican

\footnotetext{
${ }^{62}$ Hubo al parecer dos ediciones, la segunda con la adición de grabados. Hernansáez Meoro, Árboles..., pág. 31.

${ }^{63}$ La Voz de Galicia (10-02-1929), pág. 5.

${ }^{64}$ La Voz de Galicia (04-02-1927), pág 5.

${ }^{65}$ La Voz de Galicia (03-06-1931), pág. 7.
} 
que se retire otro alambre que está matando a un castaño y un negrillo, para sanarlos $^{66}$, y en 1932, cuando el Ayuntamiento anuncia su disposición de talar los eucaliptos del cementerio, Manuel Insua anuncia en los medios su disposición a disolver la sociedad para protestar contra la injusta y perjudicial sentencia de muerte $^{67}$.

En 1917 aparece la monografía El Castaño, firmada por el catedrático Hernansáez, que por entonces se había trasladado al Instituto de Cartagena. Se trata, quizás, de un intento para orientar las publicaciones hacia una línea más científica. El libro mantiene en principio una continuidad con el del eucalipto, aunque se ha cambiado el título de la serie a Árboles interesantes para Galicia, suprimiendo el adjetivo maderables. Se trata de una obra de carácter técnico, que en una treintena de páginas, tras una introducción general a la planta, pasa ocuparse de la ciencia de su aprovechamiento y mantenimiento ${ }^{68}$ : plantación, crianza en vivero e injerto, poda, abono ${ }^{69}$ y recolección. En este libro no encontramos referencias naturalistas, ni preocupación por el bienestar del árbol como ser vivo. La orientación economicista está implícita en todo el libro.

En la asociación, por tanto, conviven la vertiente naturalista y la utilitarista. La primera valora al árbol en tanto que ser vivo merecedor, si no de derechos, sí de respeto por su mera existencia, y resalta su valor para el ser humano por sus valores estéticos y ecológicos y no económicos ${ }^{70}$. Al contrario que otros postulados posteriores, no discriminaba entre especies autóctonas y alóctonas ${ }^{71}$. La segunda vertiente apela al aprovechamiento económico del árbol, en una década en la que,

\footnotetext{
${ }^{66}$ La Voz de Galicia (22-01-1936).

${ }^{67}$ La Voz de Galicia (30-09-1932), pág. 1.

${ }_{68}$ Aunque el autor admite no poder aportar ninguna solución a la peor amenaza para las devesas gallegas en este momento, el chancro del castaño, y se limita a confiar en la introducción de castaño del Japón, supuestamente inmune.

${ }^{69}$ El autor llama al empleo racional de los abonos, aconsejando el empleo periódico del nitrato de sosa, superfosfato y cloruro potásico, y recomendando el uso del abono orgánico solo cada tres o cuatro años, si la producción es parca y si se dispone de estiércol bueno. Dejando aparte que la apuesta por los fosfatos quizás pueda ser discutida, la apreciación parece alejada de la realidad agraria gallega, en la que estos químicos apenas comenzaban a ser conocidos y los rendimientos se conseguían gracias al estrume. Xesús Balboa López, Lourenzo Fernández Prieto, "Evolución das formas de fertilización na agricultura atlántica entre os séculos XIX-XX. Do toxo aos fosfatos”, en Lourenzo Fernández Prieto (ed.), Terra e progreso. Historia agraria da Galicia Contemporánea, Vigo, Edicións Xerais de Galicia, 2000, págs. 291-300.

${ }^{70}$ En alguna ocasión, recurriendo a argumentos científicos que resultan cándidos desde la perspectiva del siglo posterior. La asociación publica que los árboles eliminan el anhídrido carbónico, los vapores amoniacales y otros de naturaleza infecta. Los de crecimiento rápido, como el eucalipto, generan además ozono, que quema y destruye gran cantidad de bacilos, de esos microbios causantes de un sinnúmero de enfermedades de las que los árboles nos libran. La poda..., págs. 10-11.

71 En 1937, Manuel Insua, entonces presidente de Amigos de los Árboles, celebra la introducción y llama a traer a Galicia más especies foráneas. La Voz de Galicia (27-05-1937), pág. 2.
} 
según Gómez Mendoza, hay una inflexión economicista en la doctrina de montes española ${ }^{72}$.

\section{LA CONSOLIDACIÓN Y LA IDENTIFICACIÓN CON EL PODER (1920-1936)}

En la segunda década del siglo Amigos de los Árboles continúa teniendo un papel clave en la organización de la Fiesta del Árbol coruñesa y colabora en otras de la provincia, aunque no todos los ayuntamientos pongan cuidado a la hora de celebrarla $^{73}$. El proyecto más importante del decenio seguramente sea el arrendamiento de una parcela para vivero en el lugar de Cordeda, con capacidad para ocho mil plantones ${ }^{74}$. Se cultivan las relaciones con los ingenieros de montes, con la organización de una conferencia del profesional Jacobo Arias Villar ${ }^{75}$ o la colaboración para impartir la medalla del Mérito Agrícola al ingeniero forestal Rafael Areses ${ }^{76}$. En algún momento se producen actuaciones conjuntas con la asociación coruñesa de Naturistas, al parecer ecologistas y vegetarianos, y más frecuentemente con los Exploradores de España, la Cámara Agrícola ${ }^{77}$ y Amantes del Campo.

Pero, aunque hay algunas iniciativas menores, como la difusión del libro Árbol, de Julio J. Casal ${ }^{78}$, en 1920 y los años siguientes la asociación pierde algo del dinamismo y ebullición de proyectos de sus inicios. El golpe de Primo de Rivera en 1923 no parece alterar significativamente esta dinámica, aunque supuso un

\footnotetext{
72 Josefina Gómez Mendoza, "El naturalismo forestal”, en Josefina Gómez Mendoza, Nicolás Ortega Cantero (dir.), Naturalismo y geografía en España, Madrid, Fundación Banco Exterior, 1992, págs. 246-248.

73 Así, Amigos de los Árboles deja en 1926 de regalar árboles para fiestas a partir del 28 de febrero, negándose a colaborar con las plantaciones fuera de época que derivaban en la muerte de los árboles instalados y que seguramente se realizaban cuando el Ayuntamiento encontraba tiempo. La Voz de Galicia (13-04-1926), pág. 1.

${ }^{74}$ La parcela se encontraba en Culleredo, y, además de criar árboles, acogió actividades formativas. $\mathrm{La}$ Voz de Galicia (16-10-1924), pág. 1; (03-06-1934), pág. 2. Existe una referencia a que en 1932 Amigos de los Árboles disponía de otro vivero, sito en los terrenos de la Granja Agrícola, pero en las cuentas de la sociedad solo hemos encontrado referencias al de Cordeda. La Voz de Galicia (01-06-1932), pág. 5.

${ }^{75}$ La Voz de Galicia (05-11-1927), pág. 2

${ }^{76}$ La Voz de Galicia (03-04-1920), pág. 2. Areses sería socio, y de cualquier manera sus intereses encajaban a la perfección con los que había demostrado Amigos de los Árboles en la década anterior. En esta época el ingeniero preparó la memoria del Congreso Forestal Gallego, finalmente no celebrado, pero que tenía como objetivos fijar un plan de repoblación de los montes públicos, fomentar la riqueza pesquera y repoblación piscícola e impulsar el desarrollo de las vías de comunicación para favorecer los fines anteriores, objetivos para los que trabajó Amigos de los Árboles. Eduardo Rico BoqueTe, Politica forestal e repoboacións en Galicia, 1941-1971, Santiago de Compostela, Servizo de Publicacións e Intercambio Científico da Universidade de Santiago de Compostela, 1995, pág. 29. La Voz de Galicia (01-03-1935), pág. 1.

77 Vicente Fernández Torres, ayudante del Servicio Agronómico, dirigía tanto la Cámara como Amigos de los Árboles en 1935, fecha de su muerte. La Voz de Galicia (10-10-1935), pág. 5.

${ }^{78}$ La Voz de Galicia (26-01-1926), pág. 1.
} 
impulso a la Fiesta del Árbol en otras partes de España para aprovecharla de manera propagandística ${ }^{79}$, y a la celebración de A Coruña se incorporó el delegado gubernativo. Hay, sin embargo, comunión de intereses, puesto que las autoridades impulsaban en ese momento la repoblación forestal en Galicia con especies de crecimiento rápido.

En las actividades de la sociedad de estos años no figuran de manera prominente los republicanos más políticamente significados, aunque tampoco lo habían hecho en la década anterior. En cualquier caso, la asociación no molestaba a la Dictadura, que la integró en su entramado corporativo. En 1924 encontramos a Manuel Insua como concejal de representación corporativa, representando a la $\operatorname{sociedad~}^{80}$. Ese año, la asociación felicita al Directorio Militar por su disposición obligando a los ayuntamientos a plantar un mínimo de cien árboles anuales ${ }^{81}, \mathrm{y}$ en 1926, la sociedad se comprometió a cuidar los árboles que se plantasen en el nuevo barrio de la Ciudad Jardín ${ }^{82}$. Todavía en 1930, tras el exilio de Primo de Rivera, la asociación participaba en el censo electoral corporativo de la capital provincial ${ }^{83}$. Ese mismo año el Gobernador Civil envía una circular exhortando a los particulares y agentes de la autoridad a una mayor vigilancia para evitar incendios, y en ella señala que según me informa la Sociedad de Amigos de los Árboles de esta capital, la mayoría de los incendios se deben a descuidos de los que roturan terrenos incultos ${ }^{84}$.

Tras la Dictadura, y, sobre todo, durante la República, sobreviene la decadencia de la fiesta en otras partes de España, pero en la provincia de A Coruña no parece tan acusada ${ }^{85}$. En 1929 Amigos de los Árboles entregó 1500 árboles y 4000 folletos para diversas fiestas de la provincia ${ }^{86}$. Durante la Segunda República, el vivero de la sociedad continuaba suministrando árboles para maestros y curas párrocos que celebraban la fiesta independientemente de los ayuntamientos, además de para las fiestas municipales y para sus socios ${ }^{87}$. Aún así, en 1935 se habla de una

\footnotetext{
79 Sierra VigiL, La culta..., págs. 203-209.

${ }^{80}$ La Voz de Galicia (05-04-1924), pág. 2.

${ }^{81}$ La Voz de Galicia (04-05-1924), pág. 3; La Gaceta de Madrid (30-04-1924), pág. 579.

${ }^{82}$ La Voz de Galicia (15-12-1926), pág. 5.

${ }^{83}$ En pie de igualdad, por ejemplo, con los colegios de abogados, procuradores y notarios, la Asociación de la Prensa o la Real Academia Gallega. La Voz de Galicia (25-03-1930), pág. 1.

${ }^{84}$ La circular también señala como otra causa de incendios de masas forestales el descontrol de los los fuegos con motivo de conseguir pasto para el ganado, si bien no menciona que haya incendios con finalidad puramente destructiva. La Voz de Galicia (02-08-1930), pág. 4.

85 Sierra Vigil, La culta..., págs 245, 257-259.

${ }^{86}$ La Voz de Galicia (15-01-1930), pág 2.

${ }^{87}$ La Voz de Galicia (20-01-1933), pág. 5; La Voz de Galicia (26-01-1935), pág. 5. En 1926, y suponemos que durante todo este periodo de vida de la sociedad, los árboles para fiestas se entregaban gratuitamente. La Voz de Galicia (07-11-1926), pág. 2. A algún maestro también se le entregaron obras pedagógicas. $L a$ Voz de Galicia (03-11-1934), pág. 9.
} 
fiesta que había ido decayendo, con frialdad oficial y extremada sencillez, a la que se quiere resucitar ${ }^{88}$.

Es difícil apreciar en qué medida los vaivenes políticos de la Segunda República influyeron en Amigos de los Árboles. Ciertamente, parece que perdió carácter institucional. En 1931, la directiva seguía reservando 18 asientos para las fuerzas vivas locales, estatales o no $^{89}$, pero en la junta directiva de 1936 sólo encontramos un representante del Sindicato Agrícola ${ }^{90}$. En todo caso, sigue habiendo contactos con autoridades de distinto signo, como el alcalde republicano Manuel Iglesias Corral en $1932^{91}$. Cuando en 1934 el ayuntamiento de Oza dos Ríos decide talar cerca de cinco centenares de robles, Amigos de los Árboles consigue evitarlo a través de gestiones con el gobernador civil, el ingeniero jefe del Distrito Forestal y significados miembros del Gobierno de la República, que en estos tiempos era conservador. El segundo suspendió la tala cumpliendo órdenes superiores ${ }^{92}$, aunque hay que señalar que en estos momentos ocupaba el cargo Rafael Areses, que era miembro de Amigos de los Árboles ${ }^{93}$ y había emitido un informe negativo sobre la tala ${ }^{94}$. También existieron iniciativas conjuntas de repoblación con las autoridades militares ${ }^{95}$.

\section{Muerte y RESURRECCión BAJO EL AMPARO DEL RÉGIMEN (1936-1975)}

Los sublevados cambiaron muchas cosas cuando tomaron el poder en A Coruña, pero mantuvieron la Fiesta del Árbol, que se siguió celebrando durante los tres años de la guerra. El Nuevo Estado había decidido respetar el decreto de 1915 en la provincia, y el Gobernador Civil de A Coruña envió en 1937 una circular exhortando a su cumplimiento. Amigos de los Árboles seguía colaborando con el ayuntamiento en las celebraciones, pero estas se politizaron como nunca antes. Entre los invitados encontramos representantes de Falange y las milicias, y asientos de honor reservados para los gloriosos heridos y mutilados de guerra ${ }^{96}$. El tema de un concurso de Amigos de los Árboles en 1937 fue Patria, Bandera y Árbol, con el elemento que prestaba su nombre a la fiesta ocupando un discreto tercer

\footnotetext{
${ }_{88}$ La Voz de Galicia (23-11-1935), pág. 7.

${ }^{89}$ La Voz de Galicia (16-01-1931), pág. 7.

${ }^{90}$ Listado de la Junta Directiva de Amigos de los Árboles enviado al Gobernador Civil de A Coruña por su secretario, Celestino Caldeiro, el 6 de marzo de 1941: ARG, caja 32094, legajo 2.

${ }^{91}$ La Voz de Galicia (01-10-1932), pág. 4.

${ }^{92}$ La Voz de Galicia (27-04-1934), pág. 5.

${ }^{93}$ La Voz de Galicia (23-05-1934), pág. 5. Había sido ascendido a Ingeniero Jefe de primera clase en 1932, La Gaceta de Madrid (7-05-1932), pág. 1006.

${ }^{94}$ La Voz de Galicia (30-11-1962), pág. 8.

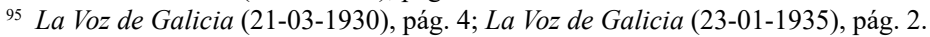

${ }^{96}$ La Voz de Galicia (20-04-1937); La Voz de Galicia (22-01-1938), pág. 4. A su vez, Amigos de los Árboles mandaba una representación corporativa a la fiesta de San Isidro Labrador. La Voz de Galicia (1405-1938), pág. 4; La Voz de Galicia (16-05-43), pág. 2; La Voz de Galicia (16-05-45), pág. 2.
} 
plano $^{97}$. Por lo demás, fuera de una protesta puntual por la tala de un eucalipto ${ }^{98}$, la actividad parece decididamente limitada. Un inventario de 1941 señala que la asociación no posee muebles ni efectos, y que en el vivero de Cordeda se criaban árboles frutales para repartir entre sus socios, sin mencionar que se usasen las plantas en las Fiestas del Árbol ${ }^{99}$.

La guerra no parece trastocar demasiado la organización de la sociedad. De los catorce miembros de la directiva de 1936 (que reserva un puesto para el representante del Servicio Agronómico, y otro para el catedrático de Agricultura), once repiten en $1941^{100}$, y los otros tres seguían perteneciendo a la agrupación. Amigos de los Árboles contaba ese año con 82 socios, lo que se corresponde con 94 personas $^{101}$, pero es el único documento de esas características que conocemos, así que no podemos saber si el conflicto hizo variar su número. En todo caso, entre los que permanecieron se encontraban miembros destacados de las élites coruñesas de posguerra ${ }^{102}$.

En 1942 la sociedad elevó una propuesta de directiva que, tras recibir un informe favorable de la alcaldía, pasó por al Gobernador Civil. Este la presentó al jefe provincial del Movimiento, del que no nos consta la respuesta, y también al inspector jefe de la Dirección General de Seguridad. El informe de este último clasifica a uno de los quince socios, José Zincke, como adicto al Régimen, a otros ocho como afectos y a otros cinco como indiferentes o de filiación desconocida. Todos ellos gozan de buena conducta moral, pública y privada ${ }^{103}$.

\footnotetext{
${ }^{97}$ Los trabajos premiados fueron Todo por España, Un español, La superficie terrestre sin árboles y El árbol desde la cuna es nuestro amigo leal. La Voz de Galicia (30-01-1937), pág. 2.

${ }^{98}$ La Voz de Galicia (14-01-1937), pág. 2.

${ }^{99}$ Listado de socios enviado al Gobernador Civil de A Coruña por el secretario de Amigos de los Árboles, Celestino Caldeiro, el 6 de marzo de 1941.

Archivo del Reino de Galicia, caja 32094, legajo 2.

Inventario de bienes de Amigos de los Árboles enviado al Gobernador Civil de A Coruña por el secretario de Amigos de los Árboles, Celestino Caldeiro, y su presidente, Manuel Monteagudo, el 6 de marzo de 1941. Archivo del Reino de Galicia, caja 32094, legajo 2.

${ }^{100}$ Listado de la Junta Directiva de Amigos de los Arboles, enviado al Gobernador Civil de A Coruña por su secretario, Celestino Caldeiro, el 6 de marzo de 1941.

Archivo del Reino de Galicia, caja 32094, legajo 2.

${ }^{101}$ Los dos socios colectivos eran el matrimonio Wonenburger, seguramente padres de la conocida matemática, y doce vecinos de las Casas Baratas. Listado de socios enviado al Gobernador Civil de A Coruña por el secretario de Amigos de los Árboles, Celestino Caldeiro, el 6 de marzo de 1941.

Archivo del Reino de Galicia, caja 32094, legajo 2.

${ }^{102}$ Entre ellos la viuda de Rodríguez Pastor, pariente y socio de Pedro Barrié de la Maza, Fernando Salorio, que llegaría a ser director general de FENOSA, y el joyero Manuel Malde, que fuera proveedor de la Casa Real.

${ }^{103}$ Informe del Inspector Jefe de la Comisaría de Investigación y Vigilancia de La Coruña remitido al Gobernador Civil de la provincia sobre los miembros de la Directiva propuesta para Amigos de los Árboles, a 25 de junio de 1942.

Archivo del Reino de Galicia, caja 32094, legajo 2.
} 
El decimoquinto es Federico García, antiguo periodista y en ese momento maestro nacional en la escuela pública Eusebio da Guarda, que formaba parte de Amigos de los Árboles desde $1913^{104}$. Según algunas fuentes, en 1918 había sido cofundador del diario conservador El Ideal Gallego, en 1919 había servido voluntariamente en África como sanitario y durante la Guerra Civil fue administrador del Hospital Militar coruñés ${ }^{105}$, si bien en la ficha policial figura que no se sabe que haya hecho nada en pro ni en contra del movimiento. El inspector afirma que consta que aunque era de derechas, fue simpatizante y ha sabido adaptar a todos los partidos de los distintos regímenes políticos. En todo caso, no era una figura incómoda para el Nuevo Estado, que lo homenajeó en diversas ocasiones ${ }^{106}$, como tampoco lo había sido Insua, fallecido en $1939^{107}$. Durante el franquismo se convertirá en el miembro más destacado de Amigos de los Árboles, alternándose en el cargo de vicepresidente o de presidente con Manuel Monteagudo (el cual, de paso, se había sacado el carnet de Falange y habló en un acto público sobre la política forestal del Régimen ${ }^{108}$ ). Representó a la agrupación en la fiesta de 1937, y a partir de ahí en adelante lo hará en prácticamente todos los actos de la sociedad hasta su muerte en 1983.

Sierra Vigil afirma que durante los años 1940 al 1959, que constituyen la etapa con mayor peso del falangismo dentro del Régimen, la fiesta del Árbol casi desapareció de España, con la excepción barcelonesa, y que el Régimen prescindió de ella pues no la necesitaba como factor de legitimación para el Nuevo Estado y la Iglesia ${ }^{109}$. Deberíamos incorporar A Coruña a las excepciones. A principios de los años cuarenta Amigos de los Árboles recibió subvenciones municipales, que, como las ayudas de la Diputación percibirá también otros años ${ }^{110} \mathrm{y}$ la fiesta siguió realizándose en la capital provincial con presencia de autoridades del Gobierno y el Movimiento. La asociación auxiliaba al Gobierno

\footnotetext{
${ }^{104}$ Juan GuILLín VARELA, "Federico García Expósito. El amigo de los árboles", en La ciudad de los periodistas: A Coruña, 53 calles y plazas con historia, A Coruña, Asociación de la Prensa de La Coruña, 2008, págs. 87-88. ${ }^{105}$ Alfonso González CAToYra, Biografias coruñesas, A Coruña, Gráfico Galaico, 1990, pág. 258. En 1930 recibió la Cruz de Beneficencia por salvar a un niño de morir ahogado en junio de 1929. El Progreso, 25-11-1930, pág. 2.

${ }^{106}$ La Voz de Galicia, (09-05-1968), pág. 22; La Voz de Galicia (17-12-1968), pág. 1, Carlos RodríGUEz DACAL, Guía verde del Pazo de Mariñán, A Coruña, Deputación Provincial da Coruña, 2015, pág. 65; $L a$ Voz de Galicia (28-01-1959), pág. 8.

${ }^{107}$ Ex militar sin afiliación política conocida, había sido condecorado en época de Berenguer y recibió homenajes con apoyo público durante el franquismo. La Voz de Galicia (20-06-1929), pág. 1; La Voz de Galicia (15-12-1939), pág. 3; La Voz de Galicia (09-02-1940), pág. 3.

${ }^{108}$ Homenaje a Luis de Luaces..., pág. 4.

${ }^{109}$ Sierra Vigil, La culta..., págs. 262-266, 323-324.

${ }^{110}$ La Voz de Galicia (04-11-1944), pág. 2; La Voz de Galicia (12-03-1965); La Voz de Galicia (30-011968), pág. 6. En las cuentas de 1949 figura una subvención municipal de cerca de mil pesetas; en las de 1950 , una de 500 .

Cuentas de la sociedad de Amigos de los Árboles de La Coruña, a 30 de marzo de 1950.

Archivo del Reino de Galicia, caja 32094, legajo 2.
} 
Civil a la hora de realizar concursos y vigilar que la fiesta se efectuase en la provincia. Un informe de 1942 señala que:

\begin{abstract}
por disposición del Señor Gobernador, esta sociedad, ha llevado cuenta de los ayuntamientos que celebraron la Fiesta del Árbol, y obedeciendo a reiteradas órdenes del mismo, se celebró en todos, menos en dos que no recibieron los árboles a tiempo ${ }^{111}$.
\end{abstract}

La agrupación había enviado una representación a 18 municipios. La fiesta se suspendió entre los años 1946 y 1949, aunque sigue celebrándose en otros puntos de la provincia ${ }^{112}$. Durante estos años se mantuvo el vivero, cuyo propósito declarado es cultivar frutales para repartir entre sus socios ${ }^{113}$, pero no hay anuncios de jornadas divulgativas ni de compras conjuntas de esquejes.

En 1950 se retoma la celebración en la capital, que ya no se interrumpirá durante el resto del franquismo ${ }^{114}$. Amigos de los Árboles está siempre presente en ella, y también, frecuentemente, en fiestas de otros ayuntamientos, si bien quedaban en ocasiones reducidas a charlas de divulgación forestal. El acto organizado en 1960 por el alcalde de Aranga, con el concurso de dos párrocos y muchos de los maestros nacionales del municipio, se inició con una misa cantada y un discurso del rector de Irixoa, seguido de la intervención de Federico García y del regidor local y la lectura de trabajos de alumnos de educación primaria. En ningún momento se plantaron árboles ${ }^{115}$.

El resurgimiento de la Fiesta del Árbol coruñesa, y, sobre todo, la atención que recibía, coincidió con el aumento de repoblaciones. En la misa y actividades de 1951 solo participaron, al parecer, Amigos de los Árboles y el Ayuntamiento ${ }^{116}$. En 1956 concurren diversas autoridades militares después encontramos en el acto al Gobernado militar, el presidente de la Diputación y diversos cargos de las Fuerzas

\footnotetext{
${ }^{111}$ Informe del secretario de Amigos de los Árboles, Celestino Caldeiro, al Gobernador Civil de A Coruña, sobre la actividad de su asociación, a junio de 1942.

Archivo del Reino de Galicia, caja 32094, legajo 2.

${ }^{112}$ Posteriormente, en los años setenta, se dirá reiteradamente que se celebró sin interrupción. Sin embargo, en 1946 se suspendió por tiempo indefinido, en ese año y los tres siguientes no hemos podido encontrar referencias, y, cuando se vuelve a celebrar en 1950, se dice en prensa que hace además varios años que la fiesta del árbol no se celebra en nuestra capital. La Voz de Galicia (17-02-1946), pág. 2, La Voz de Galicia (15-01-1950), pág. 2.

${ }^{113}$ Inventario de bienes de Amigos de los Árboles enviado al Gobernador Civil de A Coruña por el secretario de Amigos de los Árboles, Celestino Caldeiro, y su presidente, Manuel Monteagudo, el 6 de marzo de 1941. Archivo del Reino de Galicia, caja 32094, legajo 2.

${ }^{114}$ Con muy pocas excepciones. Por ejemplo, en 1952 la asociación editó un folleto publicado por el Ayuntamiento. La Voz de Galicia (10-01-1952), pág. 2.; La Voz de Galicia (23-01-1952), pág. 4.

${ }^{115}$ La Voz de Galicia (29-06-1960), pág. 2.

${ }^{116}$ La Voz de Galicia (23-01-1951), pág. 2.
} 
Armadas, la administración, los consulados y la justicia ${ }^{117}$, pero a principios de los setenta vuelve a estar restringido a representantes del Ayuntamiento, de la comunidad docente y de Amigos de los Árboles, además de los estudiantes y un párroco ${ }^{118}$.

Debemos tener presente que Amigos de los Árboles defendía a ultranza las virtudes de la repoblación, y que, independientemente de que sus miembros actuaran de buena fe, sus actividades favorecían una apuesta ideológica y económica del Régimen. En el acto antes citado, García rebatió con pruebas científicas la creencia que algunos tienen de que en Galicia, por sus abundantes lluvias, sobraban árboles, defendió el uso del terreno baldío para labradios, pastizales y bosques, y citó las riquezas que ofrecían España y otras naciones en épocas en que contaban con abundantes selvas. El discurso se produce en un momento en que la agresiva política de Patrimonio Forestal poblaba los montes gallegos no realizando compras de tierras, como en otras partes de la Península ${ }^{119}$, sino a través de convenios con ayuntamientos y Diputaciones que aprovechaban los montes comunales. Como este tipo de explotación iba en detrimento de los intereses de los propietarios (que no participaban directamente de los beneficios y se veían privados de usos de los que disfrutaban anteriormente) ${ }^{120}$, es razonable pensar que la administración veía con buenos ojos a una entidad de la sociedad civil que defendiera la repoblación como necesidad ecológica y moral.

No creemos que la explicación de la pervivencia de la sociedad coruñesa de Amigos de los Árboles pase por considerarla un instrumento ciego del Régimen. La presencia de socios influyentes y el factor de convicción personal de sus representantes fueron, sin duda, relevantes. Pero probablemente el apoyo de las autoridades se debió a que su discurso coincidía con los intereses gubernamentales. Las relaciones con las autoridades eran buenas, y la asociación ganó una cierta capacidad de influencia. En 1962, como en 1934, la asociación se opone a un nuevo intento de tala de la robleda de Pozomillos, en Oza dos Ríos. El ministro de Agricultura envió un telegrama comunicándole la paralización a Amigos de los Árboles, que seguramente, jugó un papel dentro de la movilización ciudadana para evitarla y contribuyó a dar difusión a la protesta en los medios ${ }^{121}$.

La asociación de Amigos de los Árboles franquista no puede compararse en dinamismo con la de antes de la guerra. En 1965 ingresó 1014 pesetas, casi la

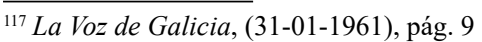

${ }^{118}$ La Voz de Galicia, (02-02-1971), pág. 6.

${ }^{119}$ Josefina Gómez Mendoza, Rafael Mata Olmo, “Actuaciones forestales públicas desde 1940. Objetivos, criterios y resultados”, Agricultura y Sociedad, 65 (1992), págs. 15-64.

${ }^{120}$ Rico Boquete, Política forestal...

${ }^{121} \mathrm{El}$ telegrama, que explicitaba que "han quedado cursadas órdenes al jefe del distrito forestal para impedir corta proyectada Ayuntamiento Oza de los Ríos, en robleda lugar de Pozomillos", se remitió también a la Asociación de Artistas y muchas otras entidades. La Voz de Galicia (20-11-1962), pág. 12.
} 
mitad de ellas provenientes de una subvención; el presupuesto, por tanto, es más reducido que en la década de 1920 en términos nominales ${ }^{122}$. Entre los 16 miembros de la directiva de ese año encontramos al ingeniero agrónomo de la Granja Agrícola y a un jardinero municipal jubilado, pero hay siete docentes en activo o retirados, varios relacionados directamente con el grupo Da Guarda ${ }^{123}$. Todos de moral intachable y sin antecedentes penales ni político-sociales desfavorables $^{124}$, pero desvinculados de la silvicultura.

A finales de los sesenta la fiesta se había convertido en un acto rutinario con el representante de Amigos de los Árboles dando su acostumbrada alocución ${ }^{125}$, muy lejos de los actos masivos de sus inicios, y los representantes de las fuerzas vivas van desvinculándose de la asistencia. Sin embargo, quizás por la fuerza de la costumbre, seguían respaldándola. En 1969, en un artículo titulado La fiesta del Árbol es obligatoria, Federico García insiste en la vigencia de la disposición de 1915; podría parecer una postura anacrónica, pero estaba refrendada por el Gobernador Civil de A Coruña ${ }^{126}$. Las llamadas de esta autoridad a celebrar la fiesta se repiten durante todas las décadas del franquismo e incluso durante la Transición, asegurando así que llegase a un importante número de ayuntamien$\operatorname{tos}^{127}$. En 1968, según García, todos los municipios de la provincia, excepto Carral y Ponteceso, responden con el mayor entusiasmo a la llamada del Gobernador Civil a celebrar la fiesta ${ }^{128}$ y en 1966, otro año en el que el Gobernador Civil recordó la obligatoriedad de la fiesta, se citan 29 municipios en los que se había celebrado o se esperaba que se celebrase ${ }^{129}$. Algunos ayuntamientos, por lo que parece, guardaron una fidelidad comparable a la de la capital ${ }^{130}$.

\footnotetext{
${ }^{122}$ Cuentas de la sociedad de Amigos de los Árboles de La Coruña para el año de 1964, firmadas por su presidente, Federico García, y su tesorero, a 28 de diciembre de 1964: ARG, caja 33192, legajo 22.

${ }^{123}$ Informe del secretario de Amigos de los Arboles al Gobierno Civil a 28 de diciembre de 1964: ARG, caja 33192, legajo 22.

${ }^{124}$ Comunicación del Brigada Comandante de la 140 Comandancia Puesto de la Guardia Civil al Gobernador de A Coruña a 11 de enero de 1965: ARG, caja 33192, legajo 22.

${ }^{125}$ La Voz de Galicia (23-01-1969), pág. 6.; La Voz de Galicia (07-02-1969), pág. 5.

${ }^{126}$ La Voz de Galicia (27-12-1969), pág. 17.

${ }^{127}$ La Voz de Galicia (31-07-1946), pág. 2; La Voz de Galicia (12-01-1954); La Voz de Galicia (26-021959), pág. 9, La Voz de Galicia (15-04-1961); La Voz de Galicia (13-3-1970), pág. 2.; La Voz de Galicia (20-01-1972); La Voz de Galicia (22-01-1975), pág. 11; La Voz de Galicia (21-10-1977), pág. 25. Muy probablemente se emitiesen circulares anuales, al menos para una parte del periodo, aunque algunos ayuntamientos las ignorasen.La Voz de Galicia (12-04-1953), pág. 7. Al menos en 1974, los municipios que no celebrasen la fiesta quedaban obligados a acoger actos de divulgación forestal. La Voz de Galicia (30-08-1974), pág. 12.

${ }^{128}$ La Voz de Galicia (10-08-1968), pág. 3.

${ }^{129}$ La Voz de Galicia (05-03-1966), pág. 15.

${ }^{130}$ En 1974, después de que Amigos de los Árboles recibiera una ayuda de la Diputación, Federico García afirmó que repartiría el dinero entre los municipios que más se han volcado en nuestras tradicionales fiestas de exaltación del árbol, señalando específicamente Ares, Teo, Vedra, Boiro, Pobra do Caramiñal y Dumbría.La Voz de Galicia (30-08-1974), pág. 20. En 1959 había declarado que los lugares de la provin-
} 


\section{LA DESAPARICIÓN DEFINITIVA (1975-1983)}

La Fiesta siguió celebrándose durante la Transición y a principios de los años ochenta $^{131}$, y de hecho, en A Coruña sigue habiendo a día de hoy plantaciones de árboles en las que participan escolares, bajo patrocinio del ayuntamiento. Sin embargo, con la democracia Amigos de los Árboles acabará relegada a un papel residual. En el acto inaugural de la Semana del Árbol de 1981 hubo una plantación y participación infantil, pero ya por el Día del Árbol, no por la Fiesta, y aunque Federico García, ya nonagenario, impartió un discurso, la organización recayó en una escuela deportiva local ${ }^{132}$. En 1982 no se le menciona a la asociación en la celebración del Día del Árbol de ese año, y, tras la muerte de García el 30 de abril de $1983^{133}$, con 96 años, Amigos de los Árboles sólo aparece en noticias de carácter histórico.

\section{Conclusiones}

En sus primeros y ambiciosos años de vida, Amigos de los Árboles aglutinó a los coruñeses de clases medias y altas interesados en varias cuestiones relacionadas con la naturaleza que empezaban a surgir en la sociedad de principios de siglo. El énfasis recayó en el sector forestal, con diferentes enfoques (desde el económico al ecológico o la educación moral), pero también estaban presentes prácticas de ocio y disfrute de la naturaleza y su aprovechamiento económico, una incipiente preocupación por los derechos de animales y plantas o la colombofilia. Sus miembros, por otra parte, no mostraron ninguna sensibilidad hacia los intereses del campesinado gallego cuando estos se oponían a la repoblación.

En la década de 1910, Amigos de los Árboles fue una asociación fuerte, solvente, con un papel importante en la implantación de la Fiesta del Árbol en la provincia más allá de la capital. En la segunda y tercera décadas del siglo mantuvo buenas relaciones con la administración, y consolidó la festividad forestal en A Coruña. Sin embargo, a partir de 1920 perdió en parte la efusión de proyectos de sus inicios. La directiva fue estabilizándose y la actividad de la asociación se hizo rutinaria, sin el dinamismo de los primeros tiempos.

La asociación fue capaz de persistir en el Régimen franquista, con una breve interrupción. En esta supervivencia probablemente jugaron varios factores: el perfil y la acción personal de su directiva; sus buenas relaciones en la sociedad

cia donde la fiesta tenía más aceptación eran la zona de Santiago, Puentedeume y Ferrol. La Voz de Galicia (28-01-1959), pág. 8.

${ }^{131} \mathrm{Y}$, como en la etapa anterior, colaborar en ella es la única actividad detectada de Amigos de los Árboles, junto con alguna protesta puntual por una tala. La Voz de Galicia (01-02-1977), pág. 42.

${ }^{132}$ La Voz de Galicia (05-04-1981), pág. 29.

${ }^{133}$ La Voz de Galicia (01-05-1983). 
coruñesa; y su papel como auxiliar del Gobierno Civil. La administración provincial, en A Coruña, apostó reiteradamente por la celebración de la Fiesta del Árbol que se extinguía en otras regiones de España. Esto último seguramente guardó relación con el enfoque repoblador del franquismo en Galicia, para el que la asociación podía ser un potencial propagandista de una política que encontraba ciertas resistencias. En los últimos años del franquismo, en los que este factor no era tan importante, el respaldo de las fuerzas vivas a la fiesta disminuyó, si bien siguieron apoyándola formalmente. Para contrastar esta tesis sería interesante un estudio comparado de la situación en otras provincias de Galicia, en las que hubo más énfasis en la repoblación que en A Coruña.

Como otras organizaciones y actitudes ligadas al Régimen, esta subsistencia trajo a cambio el agarrotamiento, la eterna repetición de esquemas y, seguramente, la vinculación emocional con el franquismo. En cuanto se desvanecieron el Estado y la persona que la habían sostenido tanto tiempo, la asociación desapareció. Paradójicamente, lo hizo en una época en la que nacían nuevas preocupaciones ecologistas en la sociedad española, pero en la que los remanentes del Régimen se habían convertido en objeto de rechazo para buena parte de ésta.

\section{BIBLIOGRAFÍA}

Balboa López, Xesús, O monte en Galicia, Vigo, Edicións Xerais de Galicia, 1990.

Balboa López, Xesús, Fernández Prieto, Lourenzo, "Evolución das formas de fertilización na agricultura atlántica entre os séculos XIX-XX. Do toxo aos fosfatos", en Fernández Prieto, Lourenzo (ed.), Terra e progreso. Historia agraria da Galicia Contemporánea, Vigo, Edicións Xerais de Galicia, 2000, págs. 275-302.

Brady, Jennifer, "El árbol y la nación: la creación de nacionalidad catalana en dos obras noucentistes", Espéculo. Revista de estudios literarios (2008).

Capelán Rey, Antón, "Contribucións a unha historia da Universidad Popular da Coruña”, Sarmiento, núm. 3, 1999, págs. 25-64.

Casado de Otaola, Santos, Los primeros pasos de la ecología en España, Madrid, Centro de Publicaciones del Ministerio de Agricultura, Pesca y Alimentación, 1997.

Casado de Otaola, Santos, Naturaleza patria: ciencia y sentimiento de la naturaleza en la España del regeneracionismo, Madrid, Marcial Pons, 2010.

Carrera Cejudo, Ángel, "La repoblación forestal. Un año en Galicia”, en Rico Boquete, Eduardo (ed.), Pensamento forestal no século XX, Santiago de Compostela, Consellería de Agricultura, Gandería e Política Agroalimentaria, Caixa Ourense, 1999, págs. 139-154. Originalmente, Madrid, 1920.

Codorniu, R., La fiesta del árbol. Recuerdos, datos, consejos, himnos, poesías, máximas y pensamientos (segunda edición), Madrid, Imprenta alemana, 1915.

Cruz Busto, Juan, Recuerdo grato de la Fiesta del Árbol. Árboles, pájaros, agricultura, etc, Logroño, El Riojano, 1900. 
El eucalipto: árboles maderables interesantes para Galicia. Instrucciones para su propagación, La Coruña, Imprenta y Papelería de F. García Ybarra, 1913.

Fernández González, Ángel I., "Los Cerdeiras. Armadores, fomentadores y conserveros de la Costa da Morte”, en Carmona Badía, Xosé (dir. y coord.), Las familias de la Conserva. El sector de las conservas de pescados a través de sus sagas familiares, Pontevedra, Diputación de Pontevedra, Fundación Clúster da Conservación de Productos del Mar, 2011, págs. 286-305.

Gómez Mendoza, Josefina, "El naturalismo forestal”, en Gómez Mendoza, Josefina, Ortega Cantero, Nicolás, Naturalismo y geografía en España, Madrid, Fundación Banco Exterior, 1992, págs. 199-274.

Gómez Mendoza, Josefina, J., Mata Olmo, Rafael, “Actuaciones forestales públicas desde 1940. Objetivos, criterios y resultados”, Agricultura y Sociedad, 65 (1992) págs. 15-64.

González Catoyra, Alfonso, Biografías coruñesas, A Coruña, Gráfico Galaico, 1990.

González Catoyra, Alfonso, Nuevas biografías coruñesas, A Coruña, Alfonso González Catoira, 1997.

Guillín Varela, Juan, "Federico García Expósito. El amigo de los árboles”, en La ciudad de los periodistas: A Coruña, 53 calles y plazas con historia, A Coruña, Asociación de la Prensa de La Coruña, 2008, págs. 87-89.

Hernansáez Meoro, José María, Árboles interesantes para Galicia: el castaño, instrucciones para su propagación, La Coruña, Papelería y talleres de la imprenta Garcybarra, 1917.

Lage, "La fiesta del árbol”, Suevia: revista gallega, Santiago de Compostela, Dirección Xeral de Política Lingüística, Centro Ramón Piñeiro para a Investigación en Humanidades, 1999, págs. 5-6. [Ed. facsimile de la revista Suevia: revista gallega publicada en La Habana en 1910-1912].

Larra, de, Fernando José, "La fiesta del árbol”, en De Larra, Fernando José, La fuente de los amores, La escuela nueva, La fiesta del árbol, Madrid, Yagües, 1929, págs. 65-76.

Martínez Cobo, José, Discurso pronunciado por D. José Martínez Cobo, Cura párroco de Bacoy, en la "Fiesta del Árbol" celebrada en Alfoz del Castro de Oro el 14 de marzo de 1926, Mondoñedo, Imprenta Popular, 1926.

Rico Boquete, Eduardo, Política forestal e repoboacións en Galicia, 1941-1971, Santiago de Compostela, Servizo de Publicacións e Intercambio Científico da Universidade de Santiago de Compostela, 1995-A.

Rico Boquete, Eduardo, "Los ingenieros de montes y la propaganda forestal: la fiesta del árbol en España", Revista Forestal Española, 12 (1995), págs. 33-37.

Rico Boquete, Eduardo, "Síntesis biográfica de un forestal gallego. Rafael Areses Vidal”, Revista Forestal Española, 16 (1997), págs. 28-31.

Rodríguez Dacal, Carlos, Guía verde del Pazo de Mariñán, A Coruña, Deputación Provincial da Coruña, 2015.

Sierra Vigil, José Miguel, La culta y simpática fiesta: la Fiesta del Árbol en la política forestal y la historia de España, Madrid, Ministerio de Medio Ambiente y Medio Rural y Marino, 2011.

Solana, Ezequiel, La fiesta del árbol (segunda edición), Madrid, El Magisterio Español, 191 ?

Villares Paz, Ramón, “A agricultura galega, 1870-1930. Unha época de grandes transformacións”, en Lourenzo Fernández Prieto, (ed.), Terra e progreso. Historia agraria da Galicia Contemporánea, Vigo, Edicións Xerais de Galicia, 2000, págs. 61-82. 